\title{
PREFERENSI PEMBIAYAAN USAHA MIKRO DAN KECIL : PERSPEKTIF GENDER DAN ENTREPRENEURABILITY
}

\author{
Khaira Amalia Fachrudin \\ E-mail : khairaamalia@yahoo.co.id
}

\begin{abstract}
Abstrak : Preferensi pembiayaan dalam perusahaan besar lebih didasarkan pada karakteristik perusahaan tersebut. Namun dalam usaha mikro dan kecil hal ini mungkin berbeda dan bergantung pada karakteristik pemiliknya seperti gender dan entrepreneurability. Perbedaan gender mungkin juga membedakan entrepreneurability dan dukungan yang diterima. Penelitian ini akan menguji apakah terdapat perbedaan preferensi pembiayaan berdasarkan gender, entrepreneurability berdasarkan gender dan berdasarkan preferensi pembiayaan, serta perbedaan dukungan berdasarkan gender. Sampel dari usaha mikro dan kecil yang bergerak dalam bidang kuliner diuji dengan uji beda Independent Sample $t$ Test dan kemudian dengan Crosstabulation untuk lebih memperinci hasilnya. Hasil uji menunjukkan bahwa tidak terdapat perbedaan yang signifikan preferensi pembiayaan berdasarkan gender dan berdasarkan entrepreneurability, namun entrepreneurability berbeda signifikan berdasarkan gender dan juga ditemukan bahwa dukungan moral, tenaga, dan modal yang diterima pemilik usaha pria dan wanita tidak berbeda signifikan ( $\mathrm{p}$ value lebih kecil dari 0.05). Hasil ini menunjukkan bahwa terdapat kesetaraan gender dalam pembiayaan usaha dan entrepreneurability lebih tinggi pada pria. Pria pemilik usaha juga mendapatkan dukungan tenaga kerja yang lebih banyak daripada wanita. Dukungan tenaga ini adalah salah satu bentuk financial bootstrapping karena dapat mengurangi pembiayaan usaha.
\end{abstract}

Kata kunci : Preferensi Pembiayaan, Entrepreneurability, Gender

\section{PENDAHULUAN}

Dalam perusahaan besar dan modern, sebagaimana dalam buku-buku teks manajemen keuangan, pemilihan sumber pembiayaan tersebut dapat bergantung pada profitabilitas, struktur modal, serta struktur kepemilikan. Tidak terdapat peran gender dalam buku-buku teks tersebut. Namun dalam usaha mikro dan kecil, karakteristik pemilik usaha akan mewarnai preferensi pembiayaannya.

Salah satu karakteristik tersebut adalah gender. Coleman (2002) serta Marlaw dan Patton (2005) dalam Eriksson, Katila, dan Ninkanen (2009) mengatakan bahwa wanita mengalami kesulitan mendapatkan pinjaman bank, mengeluarkan obligasi, menawarkan saham baru, serta mendapatkan kredit. Selain itu juga dikatakan bahwa wanita tidak menyukai hutang dibandingkan dengan pria (Coleman dan Cohn, 2000). Hal ini juga dapat dikaitkan dengan sifat wanita yang

Khaira Amalia Fachruddin, Dosen Fakultas Ekonomi Universitas Sumatera Utara 
tidak menyukai resiko terkait hormon yang ada pada dirinya. Namun Eriksson et al., (2009) menuliskan bahwa Watson et al. (2006) di Australia menemukan bahwa tidak terdapat finance gap diantara gender; di Finland wanita dan pria sama sama menggunakan dana eksternal, yaitu dari bank (Arenius dan Autio, 2006 serta Hokkanen et al., 1998), tetapi wanita lebih mudah mendapatkannya (Arenius dan Autio, 2006). Berdasarkan hal tersebut, maka dikemukakan hipotesis sebagai berikut :

Hipotesis 1 : Terdapat perbedaan preferensi pembiayaan berdasarkan gender.

Teori entrepreneurial dibuat oleh pria, untuk pria, dan tentang pria (Holmquist dan Sundin's, 1989 dalam Marlow, Shaw, and Carter, 2008). Wacana entrepreneurial didukung oleh argumen bahwa pendapat yang diterima mengenai moralitas dalam entrepreneurial dipatenkan dalam bentuk masculin gendered form (Smith dan Anderson, 2004 dalam Marlow, et al., 2008). Pesan yang melekat pada kalimat entrepreneurial adalah think entrepreneur, think male. Namun bukti menunjukkan bahwa wanita tidak mudah menerima norma seperti itu. Wanita ada juga yang sukses dengan memperoleh laba usaha sendiri yang besar walaupun ada yang menggambarkan bisnisnya sebagai hobby. Wanita yang mempunyai anak cenderung mengkombinasikan self employment dan perawatan anak sehingga kewirausahaaannya dapat mencapai keseimbangan hidup dan kerja yang dapat diterima (Marlow et al., 2008).

Literatur internasional mengatakan bahwa wirausaha wanita dan pria mempunyai tingkat motivasi, keterampilan bisnis, occupational yang berbeda, demikian juga cara mereka memulai bisnisnya, khususnya dalam hal dukungan, sumber dana dan hambatan, meskipun hanya sedikit studi yang menunjukkan perbedaan ini (Anonym). Berdasarkan hal tersebut, maka dikemukakan hipotesis sebagai berikut :

Hipotesis 2 : Terdapat perbedaan entrepreneurability berdasarkan gender.

Cara memulai bisnis dapat dikarenakan inisiatif sendiri maupun karena hal lain. Pemilik usaha yang memulai bisnis karena inisiatif sendiri mempunyai karakter kewirausahaan (enterpreneurability) yang baik dan cenderung menggunakan pendanaan nontradisional (Van Auken, 2005 dalam Gebru, 2009). Gebru (2009) menemukan bahwa pemilik usaha yang memiliki jiwa enterpreneurability yang tinggi justru lebih memilih bootstrap financing daripada pendanaan eksternal. Artinya, tidak menggunakan pendanaan dari luar dan mengupayakan apa yang ada. Berdasarkan hal tersebut, maka dikemukakan hipotesis sebagai berikut:

Hipotesis 3 : Terdapat perbedaan entrepreneurability diantara pemilik usaha berdasarkan preferensi pembiayaan.

Wanita sedikit kurang keinginan untuk memulai bisnis baru daripada pria (Van Stehl, 2003; Baker et al., 2003; dan Carter dan Marlow, 2007 dalam Marlow 
et al., 2008). Bukan berarti mereka kurang mampu atau kurang bakat, tapi wanita memerlukan dukungan (Marlow et al., 2008). Berdasarkan hal tersebut, maka dikemukakan hipotesis sebagai berikut:

Hipotesis 4 : Terdapat perbedaan dukungan berdasarkan gender.

\section{TINJAUAN PUSTAKA}

\section{Preferensi Pembiayaan}

Saat keputusan investasi dibuat, maka selanjutnya yang dipikirkan adalah keputusan pembiayaan. Pembiayaan usaha dapat berasal dari sumber internal maupun eksternal. Sumber internal berasal dari dalam dalam usaha termasuk di dalamnya laba ditahan. Sumber eksternal berasal dari luar, seperti hutang bank, obligasi, dan menerbitkan usaha baru.

Keputusan tersebut perlu mempertimbangkan biaya modal yang paling minimum. Untuk pinjaman bank, biaya modalnya adalah bunga bank, untuk obligasi biaya modalnya adalah kupon bunga obligasi yang harus dibayar serta biaya lain sehubungan dengan pengeluaran obligasi tersebut, sedangkan dalam hal saham biaya modalnya adalah dividen serta pengeluaran lain sehubungan dengan biaya lain terkait pengeluaran saham tersebut.

Pecking Order Hypothesis (POH) dikemukakan oleh Myers (1984). Dikatakan bahwa pada saat membutuhkan dana untuk investasi, perusahaan lebih suka menggunakan laba ditahan yang berbentuk aset lancar. Tingkatan preferensi selanjutnya adalah menggunakan hutang yang paling rendah resikonya sampai yang paling tinggi, terakhir adalah menggunakan sumber pembiayaan dari luar berupa ekuitas (Copeland et al., 2004).

Ward (2013b) mengatakan bahwa pemilik usaha kecil dapat menginvestasikan dana mereka sendiri ke dalam bisnis mereka, dana yang diperoleh dari warisan, tabungan, atau bahkan penjualan aset pribadi yang kemudian berfungsi sebagai pembiayaan ekuitas untuk bisnis. Membuat investasi pribadi yang berfungsi sebagai pembiayaan ekuitas dalam bisnis ini sering diperlukan untuk menarik investor lain dan atau pemberi pinjaman. Investor dan pemberi pinjaman akan melihat kontribusi pembiayaan pemilik usaha. Mereka akan melihat kontribusi pembiayaan ekuitas pemilik usaha sebagai tanda komitmennya untuk berbisnis.

\section{Entrepreneurability}

Entrepreneurability adalah istilah yang dikemukakan Gebru (2009) terkait dengan karakter kewirausahaan. Ada beberapa kontinum kewirausahaan yang merujuk pada cara masuk pemilik usaha tersebut ke pasar, yang berada di antara masuk secara sukarela sampai terpaksa. Pemilik usaha yang memulai bisnis secara sukarela memiliki orientasi bisnis yang lebih baik daripada yang menjadi pengusaha karena terpaksa. Tingkat kesukarelaan untuk masuk ini menjadi proksi tingkat entrepreneurability.

Ward (2013a ) menuliskan bahwa pemilik usaha yang mempunyai motivasi sendiri dalam memulai usaha kecil akan lebih mudah mencapai 
kesuksesan. Pemilik usaha adalah orang yang mengendalikan nasibnya sendiri dan menolak belas kasihan orang lain atau peristiwa. Mereka mengambil inisiatif dalam memulai proyek dan mendapatkan ide-ide.

\section{Gender}

Erikson et al. (2009) menuliskan bahwa wanita cenderung menggunakan tambahan dana dari pemilik yang sedia ada Bahkan, ketika wanita pemilik usaha mendapatkan kredit, mereka mendapatkannya dengan cara yang kurang elegan daripada pria karena mereka harus memiliki jaminan yang lebih banyak serta tingkat bunga yang lebih tinggi. Hal tersebut juga disebabkan karena ukuran usahanya yang lebih kecil dan hubungan dengan institusi keuangan yang kurang dekat. Namun mereka menemukan bahwa tidak terdapat pengaruh gender dalam penggunaan dana bank di Finnish. Ia juga mengatakan bahwa studi gender dan pendanaan perlu dipahami dalam konteks negara serta sifat pasar keuangan.

\section{METODE}

Populasi penelitian ini adalah usaha mikro dan kecil bidang kuliner di Jalan Arteri Medan Johor yang memiliki tempat permanen berjumlah 125 usaha. Usaha yang dipilih adalah jenis usaha yang menjual makanan dan minuman dengan penggunakan bangunan permanen. Populasi ini dipilih karena pesatnya pertumbuhan usaha kuliner di daerah ini dalam tiga tahun terakhir. Dengan menggunakan rumus dari Yamane (1973) pada margin error 10\% diperoleh jumlah sampel sebanyak 56 usaha kecil dan menengah. Pengambilan sampel dilakukan secara random.

Penelitian ini menggunakan adalah data primer yang bersifat cross section yang diperoleh melalui penyebaran kuesioner. Jenis penelitian adalah komparatif karena ingin melihat perbedaan perbedaan. Alat uji yang digunakan adalah uji beda Independent Sample t Test. Setelah diperoleh hasil, kemudian dilakukan analisis dengan Crosstabulation untuk memberi gambaran dasar keterkaitan antara dua variabel dan menemukan interaksi antar keduanya.

\section{Variabel dalam penelitian}

Penelitian ini menggunakan empat variabel, yaitu preferensi pembiayaan, gender, entrepreneurability, serta dukungan keluarga. Pengertian, skala, dan pengukuran tiap variabel dijelaskan berikut ini:

\section{Preferensi Pembiayaan}

Preferensi pembiayaan menunjukkan sumber pembiayaan mana yang lebih disukai oleh pemilik usaha mikro dan kecil. Dalam hal ini digunakan skala nominal dengan kide angka 1 dan 0 . Angka 1 dipilih bila pemilik usaha mikro dan kecil memiliki preferensi pembiayaan dari eksternal seperti pemberian dan pinjaman dari keluarga dan teman, rentenir, lembaga keuangan seperti ventura dan bank serta mengeluarkan ekuitas baru. Dalam konteks ini mengeluarkan ekuitas baru adalah bila pemilik usaha mikro dan kecil mencari mitra baru untuk berkongsi. Angka 0 dipilih bila pemilik usaha mikro dan kecil lebih memilih 
menggunakan dana internal seperti keuntungan tahun lalu yang disimpan, tabungan lain selain keuntungan usaha, dan warisan.

\section{Gender}

Gender menunjukkan jenis kelamin pemilik usaha mikro dan kecil. Ini adalah skala nominal, dimana wanita diberi angka 1, dan pria diberi angka 2.

\section{Entrepreneurability}

Merujuk pada pengertian Gebru (2009) serta dari survey awal yang dilakukan, terdapat empat pilihan berskala ordinal untuk menanyakan jiwa entrepreneurability seseorang. Pertanyaannya adalah :

Saya menjadi pengusaha yang sekarang karena :

1. Saya memang berkeinginan menjadi pengusaha

2. Usaha sambilan saya sebelumnya semakin berkembang

3. Saya tidak boleh bekerja di luar rumah

4. Dipecat dari pekerjaan sebelumnya

4. Dukungan keluarga

Variabel ini adalah variabel originalitas penelitian ini. Diukur dengan skala ordinal, yaitu :

1. Tidak ada dukungan

2. Dukungan semangat

3. Dukungan tenaga

4. Dukungan modal

\section{PEMBAHASAN}

\section{Perbedaan Preferensi Pembiayaan Berdasarkan Gender}

Hipotesis pertama mengatakan bahwa terdapat perbedaan preferensi pembiayaan berdasarkan gender. Hasil uji dengan independent sample t-test menunjukkan bahwa nilai signifikansi $\mathrm{F}$ pada Levene's test for equality of variances menunjukkan angka 1.000 . Angka yang lebih besar dari alpha 5\% ini menunjukkan bahwa terdapat kesamaan varians. Oleh karena itu digunakan uji beda t-test dengan asumsi equal variance assumed. Berdasarkan asumsi tersebut diperoleh thitung sebesar 0.000 dan $\rho$ value sebesar 1.000. Artinya tidak terdapat perbedaan preferensi pembiayaan menurut gender.

Hasil Crosstabulation dalam tabel 1 menunjukkan bahwa separuh dari wanita mempunyai preferensi pembiayaan dari eksternal, dan separuhnya adalah dari internal. Hal yang sama juga dialami oleh pria. 
Tabel 1

Hasil Crosstabulation Gender dan Preferensi Pembiayaan

\begin{tabular}{|l|l|c|c|c|}
\hline \multirow{2}{*}{} & & \multicolumn{2}{|c|}{ Preferensi Pembiayaan } & \multirow{2}{*}{ Total } \\
\cline { 3 - 5 } & & Pembiayaan internal & Pembiayaan eksternal & 24 \\
\hline \multirow{3}{*}{ Gender } & Wanita & 12 & 12 & 32 \\
\cline { 2 - 5 } & Pria & 16 & 16 & 56 \\
\hline Total & 28 & 28 & \\
\hline
\end{tabular}

Hasil penelitian menunjukkan bahwa terdapat kesetaraan gender dalam hal pemilihan sumber pembiayaan. Pengambilan keputusan pembiayaan tidak terkait gender.

Hasil penelitian ini tidak sejalan dengan Coleman, 2002; Marlaw dan Patton, 2005; Orsep et al., 2006 dalam Eriksson, et al., 2009) yang mengatakan bahwa wanita mengalami kesulitan dalam mendapatkan pinjaman bank, serta Brush, 1992; Brush et al., 2001; Coleman, 2000 yang yang mengatakan bahwa wanita lebih tidak menyukai hutang daripada pria. Penelitian ini juga tidak sejalan dengan Haynes and Haynes (1999) yang menyimpulkan bahwa wanita pemilik usaha lebih banyak meminjam dari keluarga dan teman-teman, meskipun mereka mempunyai akses yang sama dengan pria pemilik usaha untuk mendapatkan pinjaman bank. Juga tidak sejalan dengan Arenius dan Autio (2006) dalam Erickson (2009) yang mengatakan bahwa wanita pemiik usaha relatif lebih mudah mendapatkan pembiayaan daripada pria.

Penelitian ini sejalan dengan hasil di Finland, yaitu wanita pemilik usaha dan pria pemilik usaha memiliki cara pembiayaan bisnis yang sama. Keduanya menggunakan sumber pendanaan eksternal, yaitu dari bank.

\section{Perbedaan Entrepreneurability Berdasarkan Gender}

Hipotesis kedua mengatakan bahwa terdapat perbedaan entrepreneurability berdasarkan gender. Hasil uji dengan independent sample ttest menunjukkan bahwa nilai signifikansi $\mathrm{F}$ pada Levene's test for equality of variances menunjukkan angka 0.044. Angka yang lebih kecil dari alpha 5\% ini menunjukkan bahwa tidak terdapat kesamaan varians. Oleh karena itu digunakan uji beda t-test dengan asumsi equal variance not assumed. Berdasarkan asumsi tersebut diperoleh t hitung sebesar 2.524 dan $\rho$ value sebesar 0.016. Artinya terdapat perbedaan entrepreneurability berdasarkan gender. Tabel 2 di bawah ini menunjukkan hasil Crosstabulation 
Khaira Amalia Fachruddin, Preferensi Pembiayaan Usaha Mikro 101

Tabel 2

Hasil Tabulasi silang Entrepreneurability Berdasarkan Gender

\begin{tabular}{|l|l|c|c|c|}
\hline \multirow{2}{*}{ Entrepreneurability } & & \multicolumn{2}{|c|}{ Gender } & \multirow{2}{*}{ Total } \\
\cline { 2 - 4 } & keinginan jadi pengusaha & 9 & 25 & 34 \\
\cline { 2 - 4 } & $\begin{array}{l}\text { usaha sambilan } \\
\text { berkembang }\end{array}$ & 8 & 3 & 11 \\
\cline { 2 - 4 } & $\begin{array}{l}\text { dipecat dari pekerjaan } \\
\text { sebelumnya }\end{array}$ & 0 & 1 & 1 \\
\cline { 2 - 4 } & $\begin{array}{l}\text { tidak menemukan } \\
\text { pekerjaan lain }\end{array}$ & 7 & 3 & 10 \\
\hline Total & 24 & 32 & 56 \\
\hline
\end{tabular}

Dari tabel 2 di atas terlihat bahwa lebih banyak pria yang memang berkeinginan menjadi pengusaha, sementara wanita lebih banyak yang menjalaninya sebagai usaha sambilan yang kemudian berkembang serta karena tidak menemukan pekerjaan lain. Penelitian ini menunjukkan bahwa entrepreneurability lebih kuat pada pria. Hasil penelitian ini sejalan dengan yang dikemukakan Van Stehl (2003), yaitu wanita sedikit kurang keinginan untuk memulai bisnis baru daripada pria.

\section{Perbedaan Entrepreneurability Berdasarkan Preferensi Pembiayaan}

Hipotesis ketiga mengatakan bahwa terdapat perbedaan entrepreneurability diantara pemilik usaha berdasarkan preferensi pembiayaan.

Hasil uji dengan independent sample t-test menunjukkan bahwa nilai signifikansi $\mathrm{F}$ pada Levene's test for equality of variances menunjukkan angka 0.319. Angka yang lebih besar dari alpha 5\% ini menunjukkan bahwa terdapat kesamaan varians. Oleh karena itu digunakan uji beda t-test dengan asumsi equal variance assumed. Berdasarkan asumsi tersebut diperoleh thitung sebesar -0.116 dan $\rho$ value sebesar 0.908 . Artinya tidak terdapat perbedaan entrepreneurability berdasarkan preferensi pembiayaan. 
Tabel 3

Hasil Crosstabulation Entrepreneurability Berdasarkan Preferensi Pembiayaan

\begin{tabular}{|l|l|c|c|c|}
\hline & & \multicolumn{2}{|c|}{ Preferensi Pembiayaan } & \\
\hline \multirow{2}{*}{ Entrepreneurability } & $\begin{array}{c}\text { Pembiayaa } \\
\mathrm{n} \text { internal }\end{array}$ & $\begin{array}{c}\text { Pembiayaan } \\
\text { eksternal }\end{array}$ & Total \\
\cline { 2 - 5 } & $\begin{array}{l}\text { keinginan jadi pengusaha } \\
\text { usaha sambilan } \\
\text { berkembang }\end{array}$ & 15 & 19 & 34 \\
\cline { 2 - 4 } & $\begin{array}{l}\text { dipecat dari pekerjaan } \\
\text { sebelumnya }\end{array}$ & 1 & 3 & 11 \\
\hline & $\begin{array}{l}\text { tidak menemukan } \\
\text { pekerjaan lain }\end{array}$ & 4 & 6 & 10 \\
\hline Total & 28 & 28 & 56 \\
\hline
\end{tabular}

Hasil uji menunjukkan bahwa jumlah pemilik usaha yang memiliki karakter kewirausahaan yang tinggi maupun yang rendah tidak memiliki kecenderungan pada jenis pembiayaan tertentu.

Hasil penelitian ini tidak sejalan dengan Van Auken (2005) dalam Gebru (2009) mengatakan bahwa Pemilik usaha yang memulai bisnis karena inisiatif sendiri mempunyai karakter kewirausahaan (enterpreneurability) yang baik dan cenderung menggunakan pendanaan nontradisional (Van Auken, 2005 dalam Gebru, 2009). Gebru (2009) menemukan bahwa pemilik usaha yang memiliki jiwa enterpreneurability yang tinggi justru lebih memilih bootstrap financing daripada pendanaan eksternal. Artinya, tidak menggunakan pendanaan dari luar dan mengandalkan apa yang ada.

\section{Pengujian Hipotesis Keempat}

Hipotesis keempat mengatakan bahwa terdapat perbedaan dukungan diantara gender. Hasil uji dengan independent sample t-test menunjukkan bahwa nilai signifikansi F pada Levene's test for equality of variances menunjukkan angka 0.580. Angka yang lebih besar dari alpha 5\% ini menunjukkan bahwa terdapat kesamaan varians. Oleh karena itu digunakan uji beda t-test dengan asumsi equal variance assumed. Berdasarkan asumsi tersebut diperoleh t hitung sebesar -0.436 dan $\rho$ value sebesar 0.665 . Artinya tidak terdapat perbedaan dukungan menurut gender. 
Tabel 4

Hasil Crosstabulation Entrepreneurability Berdasarkan Preferensi Pembiayaan

\begin{tabular}{|l|l|c|c|c|}
\hline \multicolumn{2}{|c|}{} & \multicolumn{2}{|c|}{ Gender } & \multirow{2}{*}{ Total } \\
\cline { 3 - 5 } \multicolumn{2}{c|}{ Dukungan } & wanita & pria & tidak ada dukungan \\
\cline { 2 - 5 } & dukungan moral & 2 & 2 & 4 \\
\cline { 2 - 5 } & dukungan tenaga & 14 & 15 & 29 \\
\cline { 2 - 5 } & dukungan modal & 7 & 7 & 8 \\
\hline \multicolumn{1}{|l|}{ Total } & 24 & 32 & 15 \\
\hline
\end{tabular}

Hasil Crosstabulation menunjukkan bahwa pria dan wanita mendapat dukungan yang tidak jauh berbeda dari keluarga. Keluarga tidak pilih kasih dalam memberikan dukungan berdasarkan gender. Namun yang menarik adalah bahwa dukungan tenaga lebih banyak diperoleh pemilik usaha pria $(21,8 \%)$ daripada wanita $(4,1 \%)$. Kemungkinan adalah bahwa ketika pria menjalankan usaha, istri dan anak anak akan membantu dengan tenaganya. Namun ketika wanita membuka usaha, belum tentu anggota keluarga membantu dengan tenaganya, terutama bila suaminya memiliki usaha lain.

Temuan penelitian ini tidak secara langsung menguatkan pernyataan Gebru (2009) yang mengatakan pemilik usaha dengan entrepreneurability yang tinggi justru cenderung memilih financial bootstrapping daripada pendanaan eksternal. Tapi temuan ini menemukan bahwa pria memiliki entrepreneurability yang tinggi dan pria lebih didukung oleh keluarga dari segi tenaga. Dukungan tenaga ini adalah bentuk financial bootstrapping, karena dengan adanya dukungan ini, biaya yang dikeluarkan semakin rendah sehingga modal kerja juga bisa ditekan.

\section{KESIMPULAN}

\section{Kesimpulan}

Preferensi pembiayaan tidak berbeda antara gender. Hal ini menunjukkan kesetaraan gender dalam memilih bentuk pembiayaan. Entrepreneurability juga tidak mempengaruhi preferensi pembiayaan. Pria lebih memiliki karakter kewirausahaan yang tinggi dan lebih banyak mendapatkan dukungan tenaga dari anggota keluarga daripada wanita, walaupun secara umum dukungan yang diterima pria dan wanita tidak berbeda secara signifikan.

Sintesisnya adalah bahwa entrepreneurability lebih tinggi pada pria, namun itu tidak membedakan preferensi pembiayaan. Dukungan tenaga yang lebih banyak diterima pria dari anggota keluarga menunjukkan adanya pembiayaan non tradisional. Financial bootstrapping yang diterima lebih banyak oleh pria ini dapat menurunkan modal kerja yang diperlukan terkait pembayaran upah tenaga kerja. 


\section{Saran}

Produk produk jasa keuangan dapat ditawarkan kepada pemilik usaha pria dan wanita karena preferensi pembiayaan mereka tidak berbeda secara signifikan pada alpha 5\%. Tawaran ini juga tidak perlu mempertimbangkan karakter kewirausahaan pemilik usaha. Mungkin ada faktor lain yang membedakan preferensi pembiayaan yang tidak diteliti oleh penelitian ini, misalnya ukuran usaha dan pengalaman pemilik usaha. Penelitian selanjutnya dapat memasukkan variabel tersebut.

Financial bootstrapping berupa dukungan tenaga lebih banyak diterima pemilik usaha pria daripada wanita. Disarankan pada anggota keluarga pemilik usaha agar juga memberi dukungan tenaga pada wanita.

\section{DAFTAR PUSTAKA}

Anonym. Gender Differences in Entrepreneurship. www.ilo.org/public/english/ region/asro/bangkok/library/download/pub-96-01/chapter6.pdf. Diakses 9 Juni 2013.

Brigham, Eugene F., and Phillip R. Daves (2007), Intermediate Financial Management : Ninth Edition: Thomson - South Western.

Coleman, Susan and Richard Cohn (2000), "Small Firm's Use of Financial Leverage : Evidence from the 1993 National Survey of Small Business Finances", Journal of Business and Entrepreneurship, 12 (3), page 81-99.

Copeland, Thomas E., J. Fred Weston., and Kuldeep Shastri (2004), Financial Theory and Corporate Policy: International Edition : Prentice Hall.

Eriksson, Paivi, Saija Katila and Mervi Niskanen. (2009), "Gender and sources of finance in Finnish SMEs : a Contextual View", International Journal of Gender and Enterpreneurship, 1 (3), page 176-191.

Gebru, Gebregziabher Haileselasie (2009), "Financing Preferences of Micro and Small Enterprise Owners in Tigray : Does POH Hold ?" Journal of Small Business and Enterprise Development, 16 (2), page 322-334.

Marlow, Susan, Eleanor Shaw, dan Sara Carter, 2008. Analysing the Influence of Gender upon the Accumulation and Utilisation of Business Finance by Male and Female Entrepreneurs. Proceeding of World Conference Congres Mondial. International Council for Small Business World Conference. 
Ward, Susan (2013a). Thinking of Starting a Small Business? http://sbinfocanada. about.com/cs/startup/a/startownbiz 3.htm. Diakses 20 Juli 2013.

Ward, Susan (2013b). Equity Financing. http://sbinfocanada.about.com/cs/ financing/g/equityfinance.htm. Diakses 20 Juli 2013 